\title{
ON THE DISTRIBUTION OF ANDREAEOBRYUM IN RUSSIA
}

\section{O РАСПРОСТРАНЕНИИ ANDREAEOBRYUM В РОССИИ}

\author{
MichAel S. IGNATOV ${ }^{1,2}$, ElENA A. IGNATOVA ${ }^{1}$, ELENA I. IVANOVA ${ }^{3}$, \\ OLEG V. IVANOV ${ }^{4} \&$ NYURGUSTAN A. BYSYIN ${ }^{5}$ \\ МИХАИЛ С. ИГНАТОВ ${ }^{1,2}$, ЕЛЕНА А. ИГНАТОВА ${ }^{2}$, ЕЛЕНА И. ИВАНОВА $^{3}$, \\ ОЛЕГ В. ИВАНОВ ${ }^{4}$, НЮРГУСТАН А. БЫСЫИН ${ }^{5}$
}

Abstract

\begin{abstract}
Andreaeobryum macrosporum was considered as endemic to North America until 2015 when it was found in Yakutia. Only one locality was discovered in 2015, thus later we attempted to find out more details on its distribution, habitats and spore production. A focused search revealed a number of additional localities within two regions: in the Sette-Daban Range, within the area about $50 \times 50 \mathrm{~km}$, and in Ulakhan-Chistai Range, in the marble ridge, within the square $3 \times 5 \mathrm{~km}$. Only sufficiently wet and semi-exposed habitats are suitable for abundant sporophyte production, although the species may occur in drier areas, albeit it is usually overgrown by algae and lichens. The collections were gathered from 440 to $1400 \mathrm{~m}$ elev., but observations of adjacent distant slopes suggest its occurrence up to at least 1500-1600 m. In Ulakhan-Chistai Range, Andreaeobryum grows in virtually every stream running among cliffs, whereas in Sette-Daban its localities are few, and extensive search is required to find them. Both areas are sharply delimited, due to different bedrocks, namely quartzites and shists, in surrounding mountain ranges.
\end{abstract}

Резюме

Andreaeobryum macrosporum считался эндемиком Северной Америки до 2015 года, когда он был найден в Якутии, но только в одном месте. В последующие годы мы постарались уточнить его распространение в России, экологию и особенности репродуктивной биологии. Целенаправленный поиск позволил выявить еще ряд точек на хребте Сетте-Дабан, в пределах участка $50 \times 50$ км, а также на хребте Улахан-Чистай, на горе, сложенной мрамором, на территории $3 \times$ 5 км. Обильное спороношение отмечено только на постоянно увлажненных и не слишком открытых скалах. Хотя в ряде мест Andreaeobryum был найден растущим и в относительно сухих местообитаниях, его растения были б.ч. погребены под слоем водорослей и лишайников, выглядели угнетенными и имели в лучшем случае только единичные коробочки. Сборы были сделаны на высотах от 440 до 1400 м над ур. м., однако вид, вероятно, растет по крайней мере до высот 1500-1600 м. На Улахан-Чистае Andreaeobryum был встречен практически в каждом ручье, сбегающем со скалистого слоя, сложенного мрамором, тогда как на Сетте-Дабане его находки были результатом значительных поисков и специальных маршрутов. Оба района, где встречается Andreaeobryum, резко отграничены горами, сложенными кварцитами и сланцами, не пригодными для его произрастания.

KEYWORDS: bryophytes, biodiversity, Yakutia, rare species, spore production

\section{INTRODUCTION}

Andreaeobryum macrosporum was described by Steere \& Murray (1976) from Alaska and later found in several other localities in Alaska and also in the Yukon, the Northwest Territories (west) and in northern British
Columbia (Murray, 1988; Eckel, 2007). It remained a North American endemic up to 2015, until it was discovered in Yakutia, in Sette-Daban range, ca. $3000 \mathrm{~km}$ from closest localities in Alaska (Ignatov et al., 2016). This first record was based on a single collection at 1000

1 - Lomonosov Moscow State University, Biological Faculty, Geobotany Dept., Leninskie Gory Str. 1-12, Moscow 119234 Russia - Россия, 119234, Москва, Ленинские Горы, д. 1 стр. 12, Московский государственный университет, биологический факультет, кафедра геоботаники. E-mails: misha_ignatov@list.ru, arctoa@list.ru

2 - Tsitsin Main Botanical Garden, Russian Academy of Sciences, Botanicheskaya Str., 4, Moscow 127276 Russia - Poсcия 127276 Москва, Ботаническая 4, ГБС РАН

3 - Institute for Biological Problems of Cryolithozone of Siberian Division of Russian Academy of Sciences, 41 Lenin ave., Yakutsk, 677000, Russia - Россия 677000 Якутск, пр. Ленина, д. 41, Институт биологических проблем криолитозоны СО PAH; e-mails: bryo.ivanova@yandex.ru\& mosses07@rambler.ru

4 - P.N. Lebedev' Institue of Physics of Russian Academy of Sciences, Leninsky 53, Moscow 119991 Russia - Pоссия 119991 Ленинский проспект 534, ФИАН РАН, e-mail: ivanov@td.lpi.ru

5 - Государственная инспекция охраны природы Республики Саха (Якутия) по Томпонскому району, ул. Лесная, 6, корпус 74, п.Хандыга, Томпонский район, Якутия, Россия 


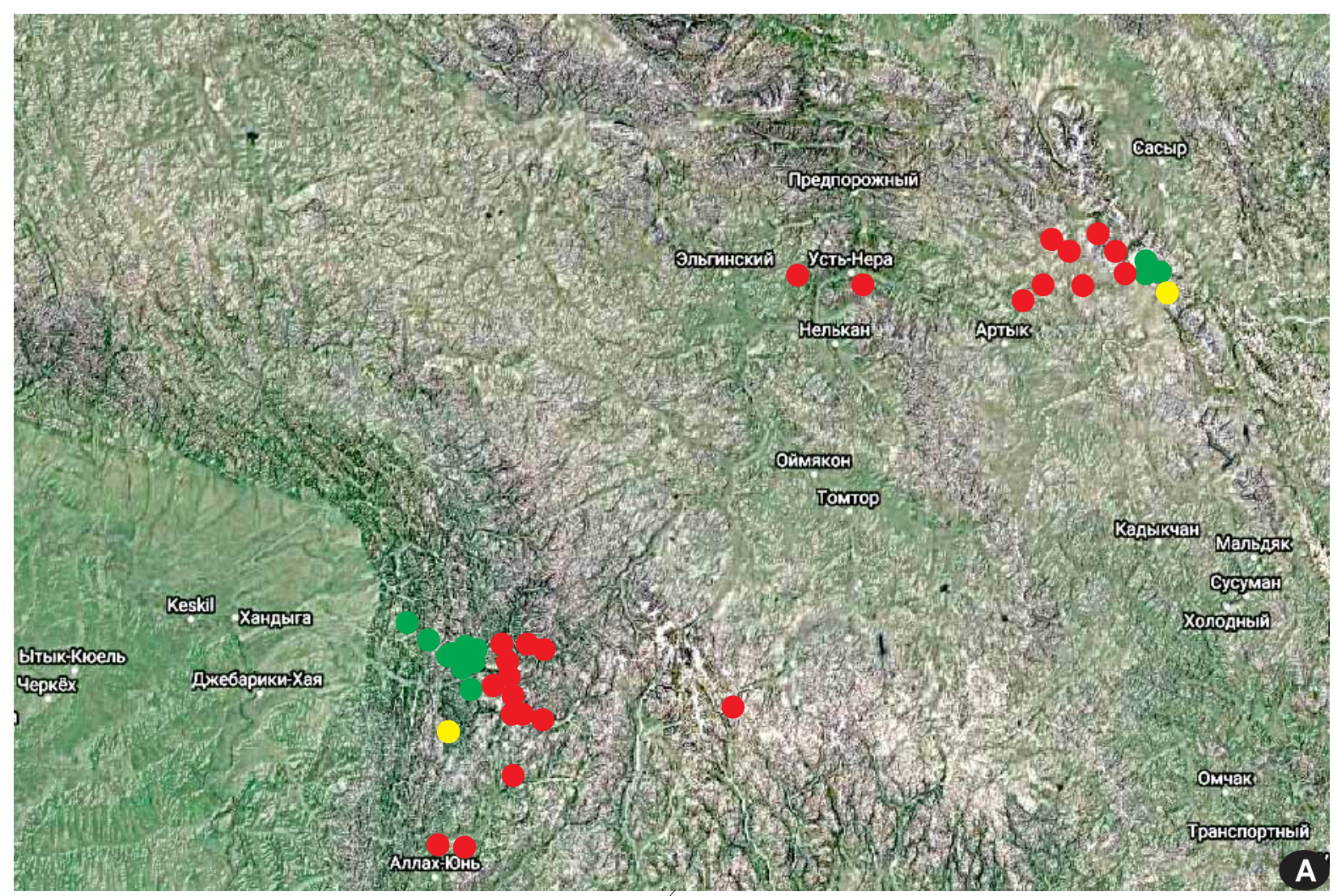

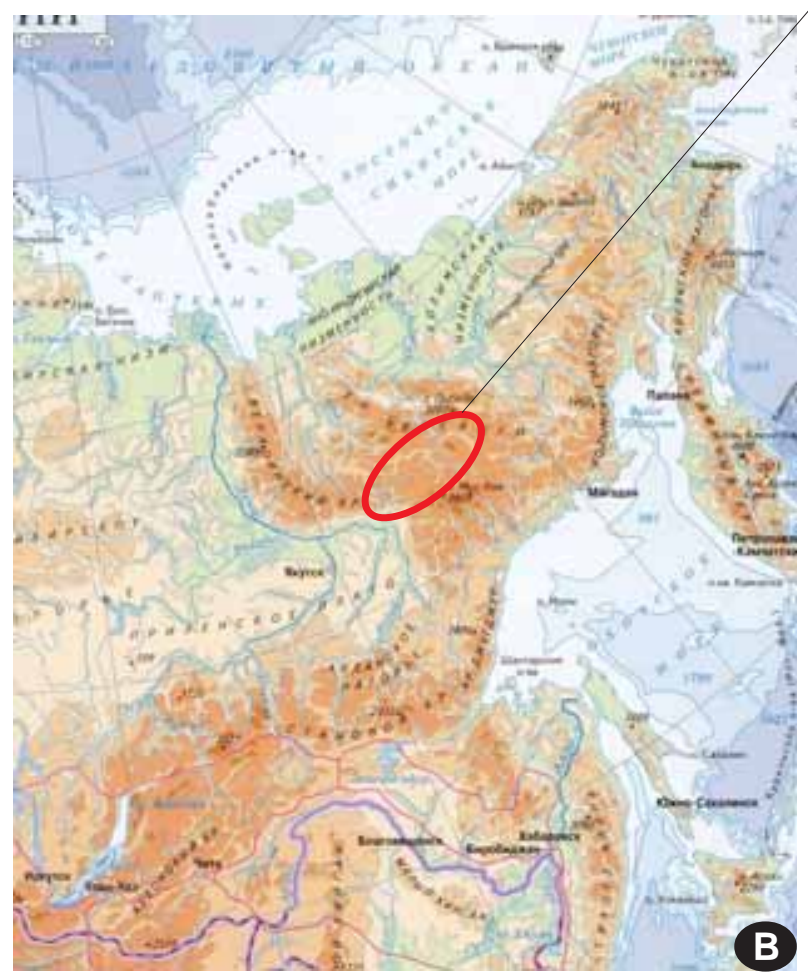

Fig. 1. Distribution of Andreaeobryum in Yakutia: green dots indicate its localities, red dots are the areas where the species has not been found in the course of rather complete field exploration by the authors; yellow marks indicate areas where the species likely occurs, assuming from similar bedrock and landscape type, but remained unexplored.
$1100 \mathrm{~m}$, shortly above tree line. The intriguing question was if this is a small population, or if more localities can be found in the area, thus we undertook a special search of the species in neighboring areas to understand its overall range and ecology, and also determine if any specific needs are required for its protection. The latter is important, as the species was included in Red Data List of Yakutia (Danilova, 2017), as comprising a relic lineage in moss evolution, and known from a limited range. The isolated systematic position of the genus, which is accepted now as a separate class of mosses (cf. Murray, 1988; Goffinet et al., 2009; Ignatov et al., 2016), raised its scientific value for conservation.

\section{FIELD EXPLORATION}

The expeditions to Yakutia in 2016 had a primary target to determine the limits of the Andreaeobryum distribution in Sette-Daban Range. Rainy weather during that expedition however gave only a limited possibility for crossing bridgeless creeks, thus the plan for a return visit was accomplished only in 2017. In 2018 we explored another region, Ulakhan-Chistay Range, selected also as an area with calcareous bedrock, where we successfully discovered Andreaeobryum as well (Fig. 1).

\section{DISTRIBUTION AND ECOLOGY}

The first discovered locality of Andreaeobryum is situated at $1000-1100 \mathrm{~m}$, shortly above timberline, which is in fact very diffuse in Yakutia. In the coldest and driest places sparse Larix cajanderi trees may reach $1700 \mathrm{~m}$ elev., especially on south-faced slopes, whereas in wetter 

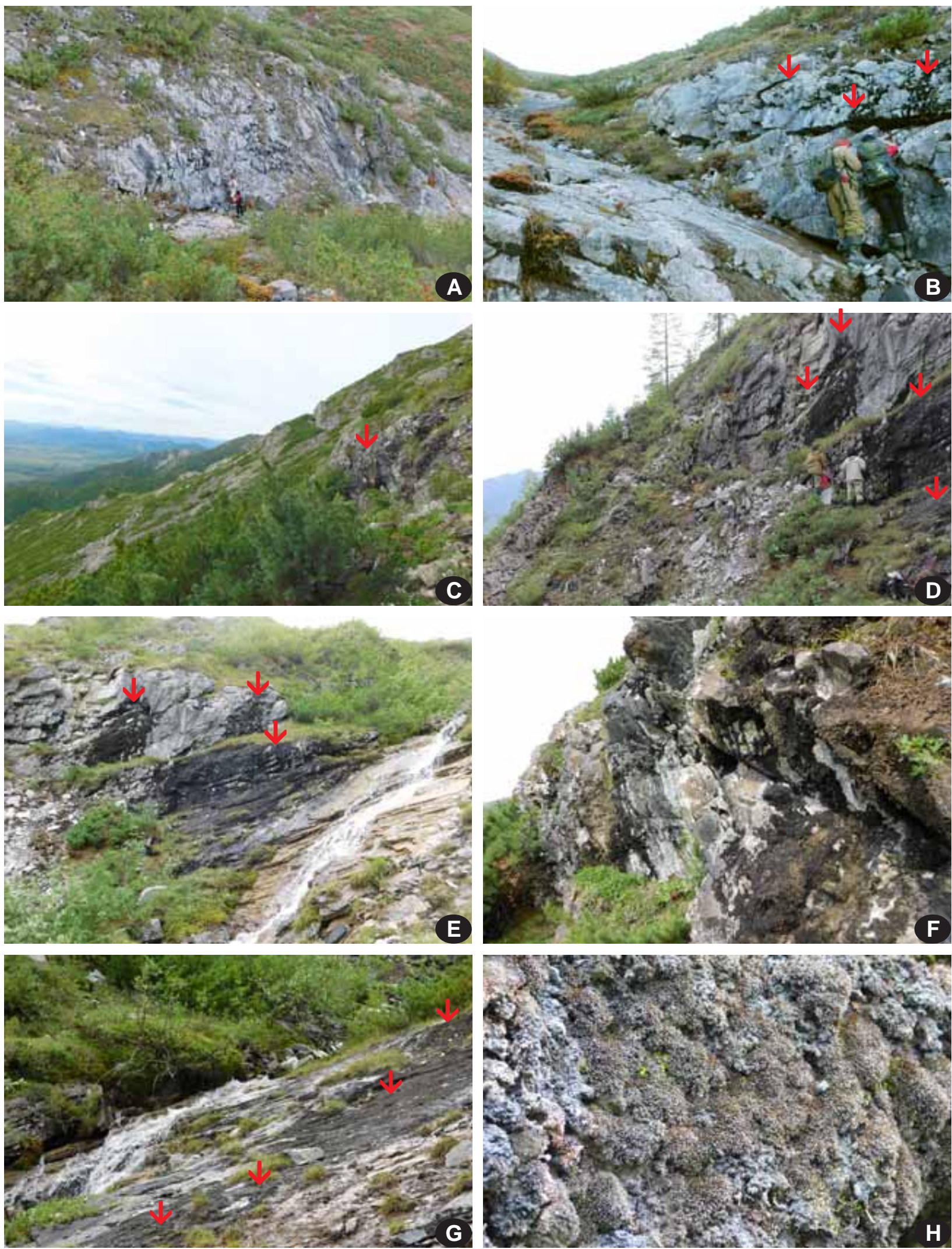

Fig. 2. Habitats of Andreaeobryum in Yakutia (Segenyakh [A-B, E-H] and Ulakh [C-D] areas): A-B: 1100 m, upper course of small stream in moderately deep valley (slopes of $20^{\circ}$ to $30^{\circ}$ ), shortly above extensive late snow bed, which is lasting up to August, but disppears by September; C-D: $1370 \mathrm{~m}, \mathrm{~W}$-faced macroslope to broad (>100 km wide) valley of Aldan River: Andreaeobryum grows on few rock outcrops on a rather open slope (sporophytes few); E-H: population in rather narrow canyon with cliffy slopes $\left(>35^{\circ}\right), 850-900 \mathrm{~m}$, where the plants are abundant not only on subvertical faces, but also on shallow rocky bottom along stream; spotty texture in $\mathrm{H}$ shows abundance of sporophytes in such favorite areas on permanently wet cliffs. Arrows point Andreaeobryum. 

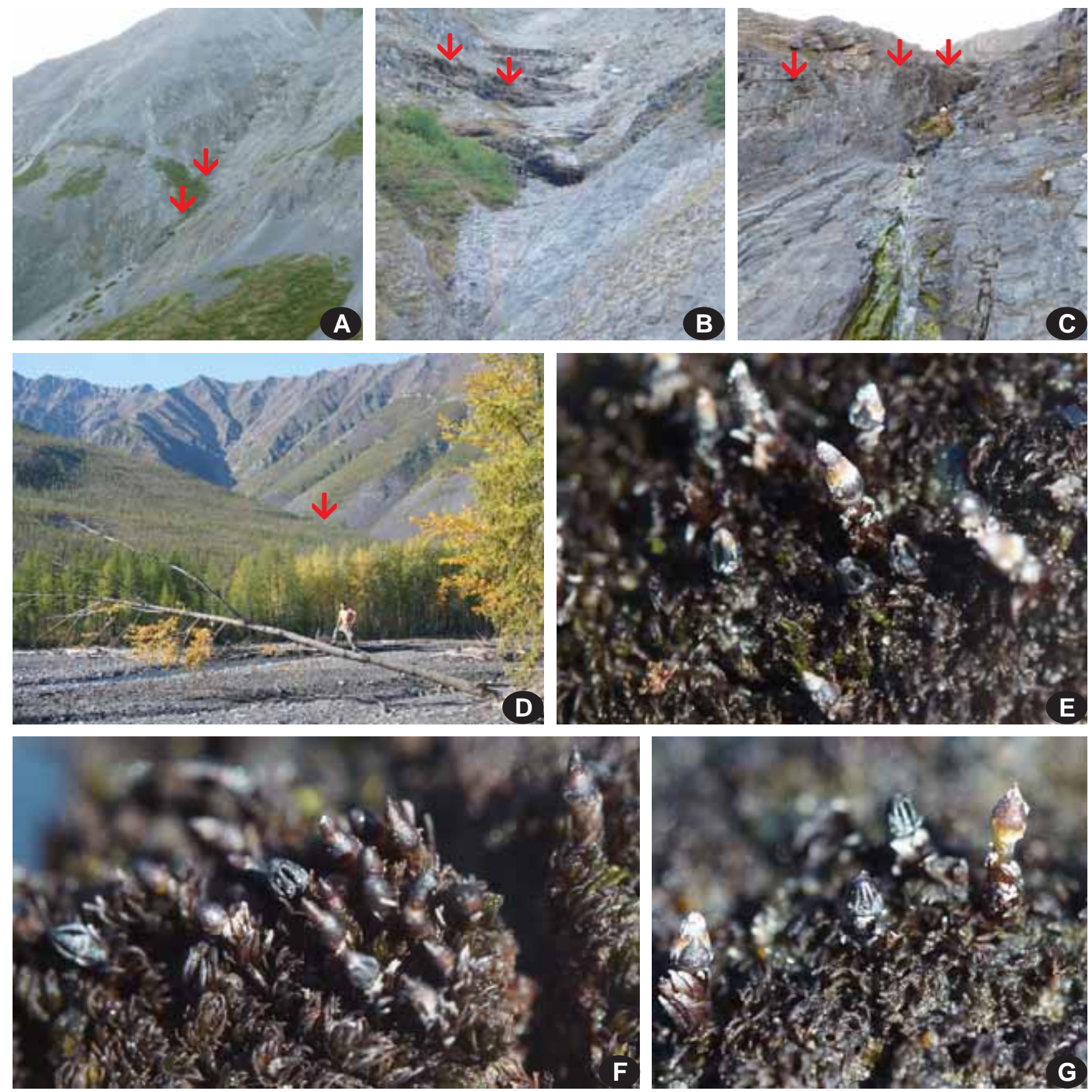

Fig. 3. Habitats of Andreaeobryum in Yakutia (Sakkyryr area): A-C: limestone ridge, where at $900 \mathrm{~m}$ elev. (B and C) Andreaeobryum occurs. D: bank of Sakkyryr River at $710 \mathrm{~m}$, with view of another ridge and valley, where Andreaeobryum occurs at $790 \mathrm{~m}$ and above on wet cliffs (arrowed), with abundant sporophyte production (E-G).

areas, e.g. in Sette-Daban Range, scattered Larix stands transit to Pinus pumila tickets at 900-1000 m. The first locality of Andreaeobryum attracted us as we noticed a snow field from the opposite slope in mid-July 2015. This site was surveyed on 19 July 2015, and described in detail earlier (Ignatov et al., 2016). It was re-visited in 2017 on 2 September (Fig. 2A-B) when snow was totally melted. The search along this stream further upstream was not successful despite the valley is bordered by rocks, but the absence of extensive solid cliffs provided no suitable habitat to Andreaeobryum. Separate boulders up to even three meter seem not to be stable enough for starting a new population.
Naturally, our first attempts to find Andreaeobryum were directed to the timberline and above, in relative proximity to the first discovered locality. We were successful in finding new occurrences both $2 \mathrm{~km}$ apart, and ca. $20 \mathrm{~km}$ from the original population. The larger population (Fig. 2E-H), was found along a relatively small stream (early August), although with extensive flat rocks along the stream bed indicating temporarily much stronger flooding. Wet cliffs had plants with numerous sporophytes (Fig. $2 \mathrm{H})$. This population was confined to the $100-150 \mathrm{~m}$ where the stream is especially fast descending in a series of small waterfalls, thereby making exposed cliffy banks, the main habitat of Andreaeobryum. In fact, the first discovered lo- 

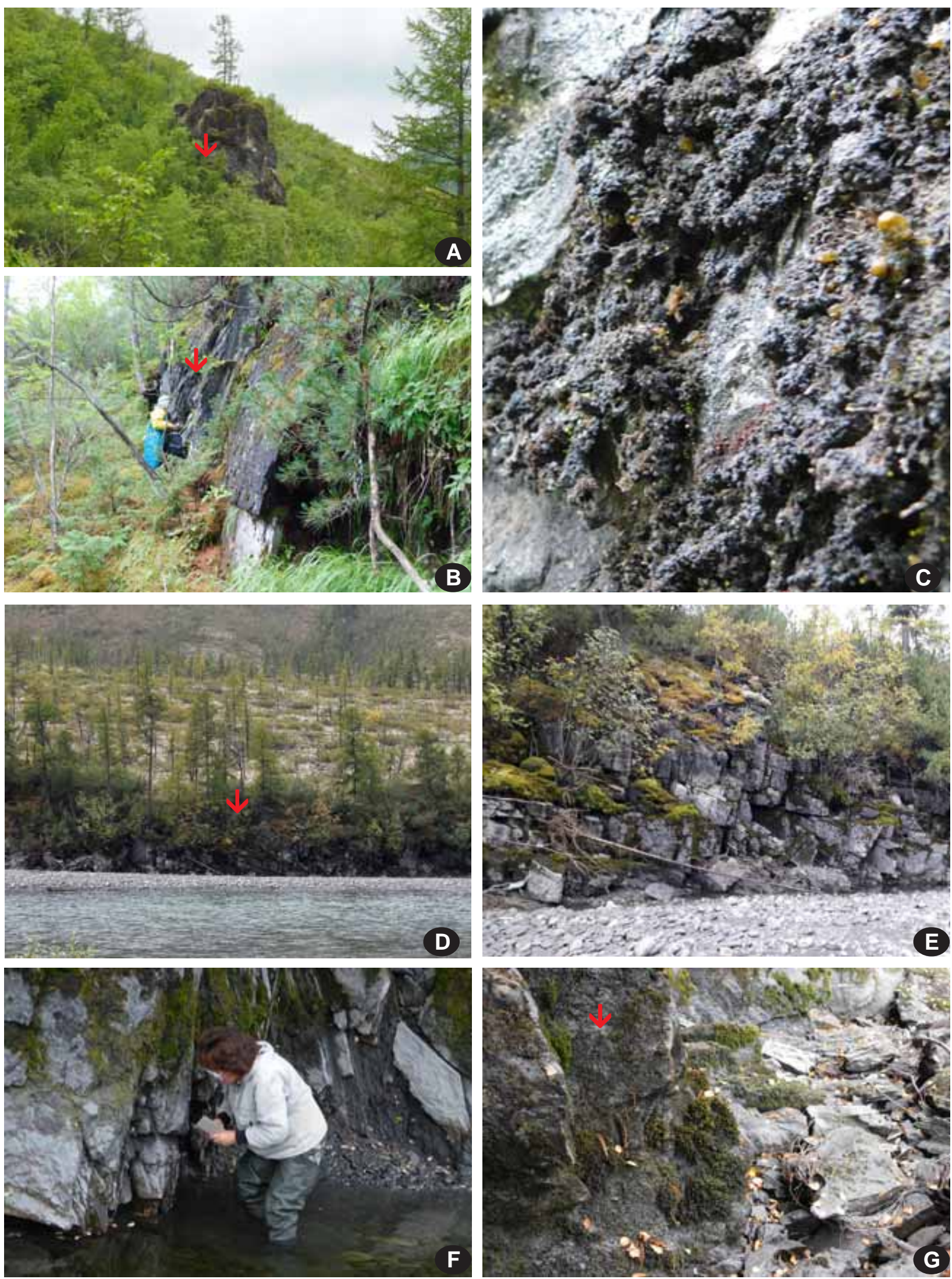

Fig. 4. Distribution of Andreaeobryum in Yakutia (A-C: Nadezhda Creek area, D-G: left bank of Vostochnaya Khandyga River opposite Segenyakh Creek mouth). A-B: cliff at foothill in the forest, $500 \mathrm{~m}$, where Andreaeobryum occurs as strongly degraded plants among algae and lichens (C), almost without sporophytes. D-G: temporary flooded limestone outcrops along Vostochnaya Khandyga River, 440 m, Scouleria habitat, where solitary shoots of Andreaeobryum were found in tuft of Hymenostylium recurvirostrum in the course of identification. 

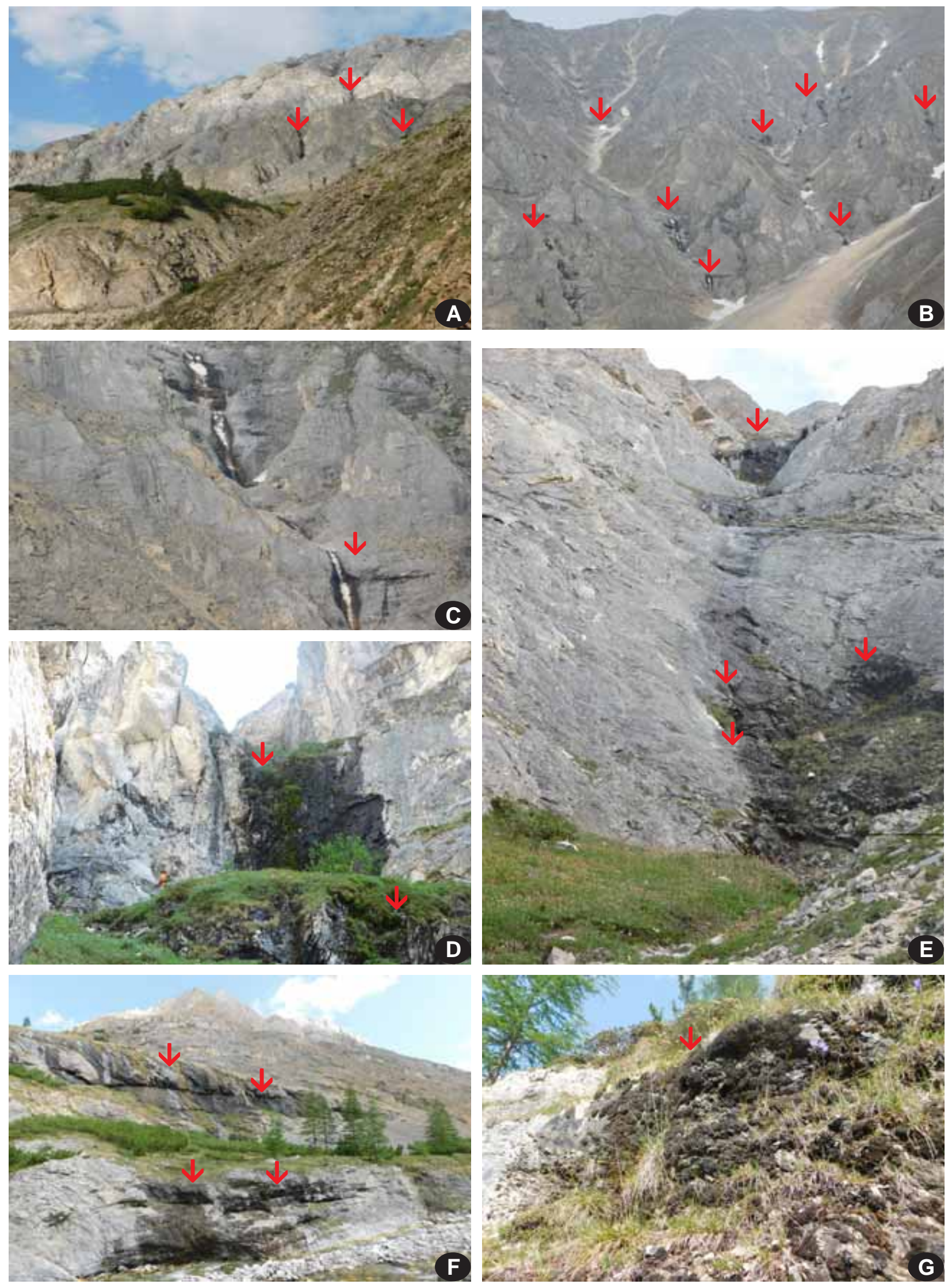

Fig. 5. Distribution of Andreaeobryum in Yakutia (Mramornaya [=Marble] Mt. area). Collections were done at 950 to $1150 \mathrm{~m}$, while black sides along waterfalls on slope point the species occurrence in many more places, at least up to about $1500 \mathrm{~m}$ (peak is above $1800 \mathrm{~m}$ ). G shows the species localities in the creek bottom, where it occir in open places (as shown here), in addition to more shady cliffs, similar to those shown in Fig. 2E. Sporophytes in places similar to G are very few. 
cality also occurs in the site where the stream crosses an area with numerous small waterfalls and cliffy banks.

Another place (Fig. 2C-D) was found on a west-faced open slope at the edge of Sette-Daban Range, faced to the expanded plain of the Aldan River Valley. Andreaeobryum grows here in rather exposed habitats, which however are faced to western winds, thus accepting extra moisture compared to mountain areas within the more eastern highland. In addition, Andreaeobryum was collected here at higher elevations, $1300-1400 \mathrm{~m}$, also meaning a longer snow period and less evaporation.

However, shortly after that we unexpectedly located Andreaeobryum also at lower elevations: on a cliff in the forest (Fig. 4A-B), although it was quite hidden in the half decomposed mass of lichen and algae (Fig. 4C). Further search at about $500 \mathrm{~m}$ revealed it in two other places. In small, narrow and very cold (due to constant cold wind from its inner areas) canyon it was seen at cliff bases and occasionally submerged on rocks on fast running water.

Another locality was found along the Vostochnaya Khandyga River (Fig. 4D-G), but in such a small quantity that field observation failed to notice it and only during subsequent study in the laboratory a few shoots were extracted from a Hymenostylium recurvirostrum tuft. This river has a great fluctuation in water level and often it is impossible to cross it by any means, however, during low flows sometimes rubber boots are enough to cross it. A relatively low level (Fig. 4D), opened ca. $2 \mathrm{~m}$ of cliff bases, with abundant Scouleria pulcherrima, Anomodon minor, Schistidium spp., Hygrohypnum luridum and Hymenostylium. However, big blocks along the river bank never have abundant Andreaeobryum.

Numerous attempts to find Andreaeobryum in the eastern part of Sette-Daban, along the Kuraanakh Creek (left tributary of Vostochnaya Khandyga River) and Dyby River (right tributary of Tyry River) failed (cf. Fig. 1), as schist rocks seem to be totally an unsuitable substrate for Andreaeobryum. Schist cliffs decompose easily, being quite unstable and dry, and therefore, very poor in bryophyte cover (Ignatova et al., 2018). Within the limestone areas there are some valleys with schist rocks, thus Andreaeobryum occurs in the Sette-Daban area but is fairly scattered, although altogether ten localities were recorded. In the course of a trip from Kuraanakh Creek to the west along the Sakkyryr Creek (left tributary of Vostochnaya Khandyga River), we returned from schist part of Sette-Daban to limestone area, where two more localities of Andreaeobryum were discovered (Fig. 3).

The second area of Andreaeobryum in Russia has been found in the Ulahan-Chistai Range, not far from the highest peak of Yakutia, the Pobeda Mt, $3003 \mathrm{~m}$ elev. (Figs. 1,5). Andreaeobryum was found on Mramornaya Mountain, at 950 to $1150 \mathrm{~m}$, but black areas along waterfalls on cliffy slopes indicated its occurrence up to $1500-1600 \mathrm{~m}$ (Fig. 5). This mountain comprises a monolithic massif about $20 \times 5 \mathrm{~km}$, but sharply surrounded by quarzites with high content of iron and apparently also with heavy metals, judging from the Mielichhoferia and Coscinodon present at this locality. The latter rock type is incompatible with any environments where Andreaeobryum may grow, thus this locality in Ulakhan-Chistai Range is even more sharply delimited than that in the Sette-Daban Range.

Considering other explored areas, the overall range of this plant looks quite logical, being confined to two flanks of a great mountain systems, Verkhoyansky Range and Chersky Range, which form an area mainly of acid igneous and metamorphic rocks, and only at places flanked by sedimentary calcareous areas suitable for Andreaeobryum. The red dots in Fig 1 are partly taken from our previous studies (Ignatov et al., 2001; Ignatova et al., 2011; Ivanova et al., 2016. 2018; ) as well as unpublished sources.

\section{ACKNOWLEDGEMENTS}

We are sincerely grateful to James Shevock for improving English of the manuscript. The study of Ignatov and was supported by RFBR 15-29-02647, of Ignatova and Ivanova by RFBR 16-04-01156 and activities of Ivanova were done in the course of Project VI.52.1.8 (Fundamental and applied aspects of biodiversity studies of plants of North and Central Yakutia (0376-2016-0001; AAAA-A17-117020110056-0).

\section{LITERATURE CITED}

ECKEL, P.M. 2007. Andreaeobryaceae. - In: Flora of North America Editorial Committee (eds.) Flora of North America North of Mexico 27: 108-110.

[DANILOVA, N.S. (ed.)] ДАНИЛОВА Н.С. (отв. ред.). 2017. Красная книга Республики Саха (Якутия). Т. 1: Редкие и находящиеся под угрозой исчезновения виды растений и грибов [3-е изд.]. - [Red Data List of the Republic Sakha (Yakutia). Vol. 1. Rare and endangered species of plants and fungi (3d edition)] M.: Peapm [Moscow: Reart], $412 \mathrm{pp}$.

GOFFINET, B., W.R. BUCK \& J. SHAW. 2009. Morphology, anatomy, and classification of the Bryophyta. - In: Goffinet, B. \& J. Shaw (eds.) Bryophyte Biology (ed. 2). Cambridge University Press, Cambridge, U.K., 55-138.

IGNATOV, M.S., E.I. IVANOVA, E.A. IGNATOVA \& K.K. KRIVOSHAPKIN. 2001. On the moss flora of Ust-Maya District (Republic Sakha/Yakutia, East Siberia). - Arctoa 10: 165-184.

IGNATOV, M.S., E.A. IGNATOVA, V.E. FEDOSOV, O.V. IVANOV, E.I. IVANOVA, M.A. KOLESNIKOVA, S.V. POLEVOVA, U.N. SPIRINA \& T.V. VORONKOVA. 2016. Andreaeobryum macrosporum (Andreaeobryopsida) in Russia, with additional data on its morphology. Arctoa 25: 1-51.

IGNATOVA, E.A., E.I. IVANOVA, O.V. IVANOV, M.S. IGNATOV. 2011. Mosses of the Mus-Khaya Mountain (Yakutia, Asiatic Russia). -Arctoa 20: 211-226.

IGNATOVA, E.A., E.I. IVANOVA, V.G. ISAKOVA \& M.S. IGNATOV. 2018 Moss flora of Sette-Daban Range (Yakutia). - Arctoa 27: 119-130.

IVANOVA, E.I., E.A. IGNATOVA \& M.S. IGNATOV. 2016. Moss flora of the Suntar-Khayata Reserve, Yakutia). - Arctoa 25: 131-140.

IVANOVA, E.I., E.A. IGNATOVA, V.G. ISAKOVA, I.A. BALAKIREV, O.I. KUZNETSOVA \& M.S. IGNATOV. 2018. Moss flora of Ust-Nera region in the upper course of Indigirka River, East Yakutia. - Arctoa 27(1): $18-28$

MURRAY, B.M. 1988. Systematics of the Andreaeopsida (Bryophyta): two orders with links to Takakia. - Beihefte zur Nova Hedwigia 90: 289-336.

STEERE, W.C. \& B.M. MURRAY. 1976. Andreaeobryum macrosporum, a new genus and species of Musci from northern Alaska and Canada.Phytologia 33: 407-410. 